Article

\title{
Wetland Accretion Rates Along Coastal Louisiana: Spatial and Temporal Variability in Light of Hurricane Isaac's Impacts
}

\author{
Thomas A. Bianchette ${ }^{1, *}$, Kam-biu Liu ${ }^{2}$, Yi Qiang ${ }^{3}$ and Nina S.-N. Lam ${ }^{4}$ \\ Received: 3 November 2015; Accepted: 16 December 2015; Published: 22 December 2015 \\ Academic Editor: Richard Smardon \\ 1 Department of Oceanography and Coastal Sciences, School of the Coast and Environment, 3251 Energy, \\ Coast, and Environment Building, Louisiana State University, Baton Rouge, LA 70803, USA \\ 2 Department of Oceanography and Coastal Sciences, School of the Coast and Environment, 1002Y Energy, \\ Coast, and Environment Building, Louisiana State University, Baton Rouge, LA 70803, USA; kliu1@lsu.edu \\ 3 Department of Environmental Sciences, School of the Coast and Environment, 1273 Energy, Coast, \\ and Environment Building, Louisiana State University, Baton Rouge, LA 70803, USA; yqiang1@1su.edu \\ 4 Department of Environmental Sciences, School of the Coast and Environment, 2275 Energy, Coast, \\ and Environment Building, Louisiana State University, Baton Rouge, LA 70803, USA; nlam@1su.edu \\ * Correspondence: tbianc1@tigers.lsu.edu; Tel.: +1-225-578-0470; Fax: +1-225-578-6423
}

\begin{abstract}
The wetlands of the southern Louisiana coast are disappearing due to a host of environmental stressors. Thus, it is imperative to analyze the spatial and temporal variability of wetland vertical accretion rates. A key question in accretion concerns the role of landfalling hurricanes as a land-building agent, due to their propensity to deposit significant volumes of inorganic sediments. Since 1996, thousands of accretion measurements have been made at 390 sites across coastal Louisiana as a result of a regional monitoring network, called the Coastal Reference Monitoring System (CRMS). We utilized this dataset to analyze the spatial and temporal patterns of accretion by mapping rates during time periods before, around, and after the landfall of Hurricane Isaac (2012). This analysis is vital for quantifying the role of hurricanes as a land-building agent and for understanding the main mechanism causing heightened wetland accretion. The results show that accretion rates averaged about $2.89 \mathrm{~cm}$ /year from stations sampled before Isaac, $4.04 \mathrm{~cm} /$ year during the period encompassing Isaac, and $2.38 \mathrm{~cm} /$ year from sites established and sampled after Isaac. Accretion rates attributable to Isaac's effects were therefore $40 \%$ and $70 \%$ greater than before and after the event, respectively, indicating the event's importance toward coastal land-building. Accretion associated with Isaac was highest at sites located 70 kilometers from the storm track, particularly those near the Mississippi River and its adjacent distributaries and lakes. This spatial pattern of elevated accretion rates indicates that freshwater flooding from fluvial channels, rather than storm surge from the sea per se, is the main mechanism responsible for increased wetland accretion. This significance of riverine flooding has implications toward future coastal restoration policies and practices.
\end{abstract}

Keywords: wetland accretion; Hurricane Isaac; Coastal Reference Monitoring System (CRMS); Mississippi River; flooding; rainfall; storm surge

\section{Introduction}

\subsection{Research Problem}

Wetland loss is a major problem in coastal Louisiana today. From 1932 to 2010, approximately $4900 \mathrm{~km}^{2}$ of wetlands have disappeared from the Louisiana coast [1], largely from erosion and drowning caused by rising sea level, subsidence, and sediment depletion from the construction of 
levees, dams, and canals. With sea level rise projected to accelerate throughout the 21st century [2], future land loss is projected to be significant throughout southern Louisiana's wetlands [3-5]. Since these environments provide suitable areas for wildlife habitats, commercial fisheries, storm surge protection, oil and gas production, and infrastructural development, the futures of coastal stability, conservation, and restoration are important environmental and economic issues.

Vertical accretion rate is an important variable in determining wetland stability. Defined as the measure of accumulation from organic and mineral materials on the wetland surface, vertical accretion is affected by many anthropogenic (levee, dam creation) and natural (salinity, hydrology) factors. These wetland accretion rates can be readily compared to relative sea level rise (RSLR) [6] and shallow subsidence rates [7] to determine coastal susceptibility to flooding and land loss. Despite relatively low RSLR rates (3.4-6.9 mm/year) [8] along Southwestern Louisiana, the Mississippi River Deltaic Plain in Southeastern Louisiana experiences an accelerated RSLR rate $(9.27 \mathrm{~mm} /$ year) [9] and high shallow subsidence rates, approaching $25 \mathrm{~mm}$ /year [7], indicating a serious risk toward increased marine flooding and subsequent coastal erosion and land loss.

Accretion studies along coastal Louisiana began in the 1970s and 1980s [10-13] and have continued through recent times [14,15], with a synthesis provided by Jarvis [16]. While the implementation of ${ }^{137} \mathrm{Cs}$ and ${ }^{210} \mathrm{~Pb}$ dating techniques has greatly improved temporal resolution by enabling a determination of accretion rates going back 50+ years, the spatial coverage of accretion study sites remains insufficient. Additionally, challenges have arisen in compiling and synthesizing accretion data from the literature because accretion rates determined by different techniques and methodologies (e.g., ${ }^{137} \mathrm{Cs}$, ${ }^{210} \mathrm{~Pb}$, feldspar method) are difficult to be compared directly. Therefore, there is a strong need for the compilation and mapping of accretion rates determined by the same method of measurement at wetland sites throughout Southern Louisiana.

A geographic information system (GIS) permits an improved understanding of the spatial and temporal variability of accretion rates in our wetlands, which is vital for an assessment of the long-term sustainability of coastal Louisiana. In this study we used accretion rate data extracted from the Coastal Reference Monitoring System (CRMS) database to analyze and map the spatial and temporal variability of vertical accretion rates in the coastal wetlands of Southern Louisiana focusing on three time periods: before Hurricane Isaac, encompassing Isaac, and after Isaac. A comparison of the changes in accretion rates over the three periods, which were measured consistently by means of the same method, allowed us to evaluate the role of Hurricane Isaac as an agent of wetland accretion and, as a corollary, a "land builder" in Southern Louisiana.

The contribution of landfalling hurricanes (Figure 1) toward the delivery of sediments to coastal wetlands throughout southern Louisiana has been established. A pioneer study by Baumann and others [13] highlighted the importance of hurricane-induced sedimentation to annual vertical accretion rates. Analyzing deposition from the landfall of Hurricane Andrew (1992), Nyman and others [17] found that hurricane-induced sedimentation originated from lakes and bays located east of the storm track, where wetland vertical accretion rates were up to 11 times greater than annual rates. Cahoon and others [18] found that vertical accretion rates throughout Terrebonne and Barataria Basin sites were 2-12 times higher during periods encompassed by Hurricane Andrew's landfall than periods before and after this event. While these studies have improved our understanding of the impacts of hurricanes on wetland accretion, recent studies have yet to provide both a large-scale geographical, and temporal assessment on the magnitude of such storm deposition in the context of the background accretion rates before and after the event.

Here, we focus on Isaac, the most recent landfalling hurricane in Louisiana that left a significant geological and socio-economic impact to the state. In this paper, we address three main research questions. First, did Isaac cause massive sediment deposition across Southern Louisiana, leading to increased vertical accretion rates when compared to periods before and after the event? Secondly, if Isaac caused massive sediment deposition across Southern Louisiana, are accretion rates highest nearest the coast and along the storm track, mimicking patterns of hurricane-induced sediment 
deposition [19]? Finally, were increased vertical accretion rates caused mainly by storm surge inundation or by riverine flooding?

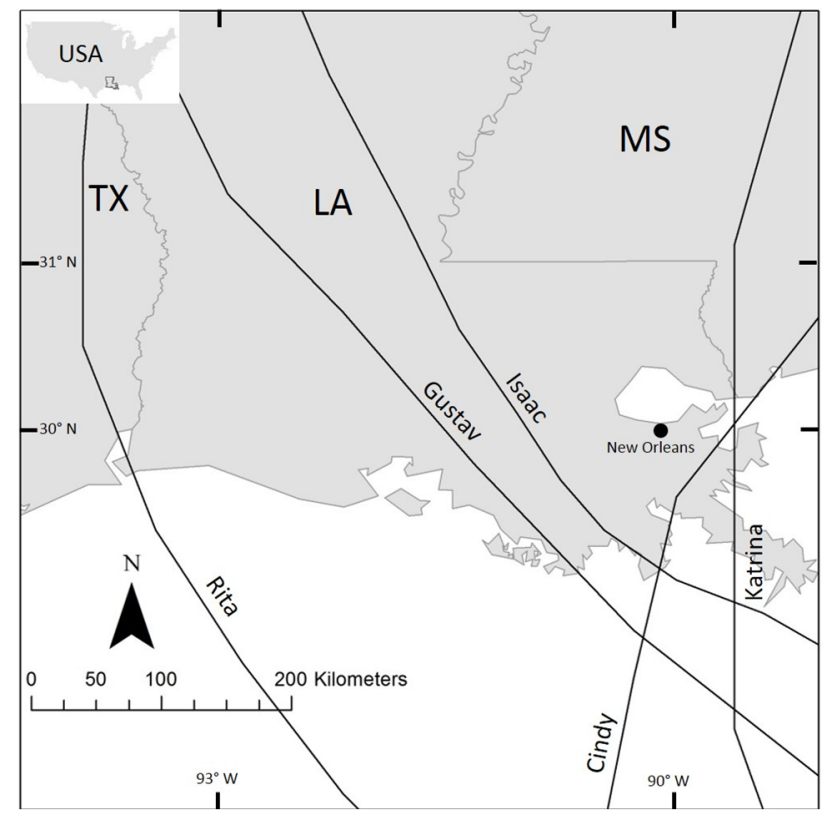

Figure 1. All hurricane tracks (category 1-5 intensity) making direct landfall on the southern Louisiana coast from 2005 to 2014.

\subsection{Study Area}

Southern Louisiana consists of two distinct geological regions: the Mississippi River Delta, and the Chenier Plain. Throughout the last 7500 years, dynamic interactions between fluvial and coastal processes formed a series of offshore shoals and barrier islands, in addition to six subdelta complexes responsible for much of the land building throughout Southeast Louisiana [20]. The construction of dams and levees in the past century has restricted the flow of the Mississippi River and its tributaries, drastically reducing flood-induced sediment deposition and land building in the floodplain and wetlands while the accelerated subsidence and saltwater intrusion has rapidly eroded this coastal area. The shell- and sand-dominant Chenier Plain along Louisiana's southwest coast was formed largely by the deposition and accumulation of offshore sediments transported via the meandering Mississippi river and its shifting deltas [21]. Throughout Louisiana, vegetation nearest the coast is dominated by salt marsh, with a gradual inland transition to brackish marsh, intermediate marsh, fresh marsh, and swamp [22]. Grasslands and agricultural fields are common in higher elevated areas further north, especially north of Lake Maurepas and Lake Pontchartrain.

\subsection{Hurricane Isaac}

Hurricane Isaac (Figure 1) made landfall in the evening of August 28, 2012 near the mouth of the Mississippi River as a category 1 storm (winds $\sim 80 \mathrm{mph}$, pressure $967 \mathrm{mb}$ ). Isaac reentered the Gulf briefly, and made a second landfall (winds $\sim 80 \mathrm{mph}$, pressure $966 \mathrm{mb}$ ) near Port Fourchon (Lafourche Parish) in the morning of August 29. A $70 \mathrm{~km}$ coastal buffer from Isaac's track contained the highest sustained winds (> 55 mph) [23]. Isaac was unique due to its large size, slow speed, and heavy rainfall, flooding southern Louisiana with totals of 8-15 inches $(20-38 \mathrm{~cm})$ of rain to the west and north of lakes Maurepas and Pontchartrain and 9-14 inches $(23-36 \mathrm{~cm})$ spanning inland from the Gulf of Mexico to Lake Pontchartrain [24]. Isaac's slow motion was also a significant factor causing high storm surge totals, resulting in widespread inundation of Southern Louisiana's lakes, bays, inlets, and distributaries. The highest storm surge $(\sim 5 \mathrm{~m})$ occurred throughout the Mississippi River Delta, 
mainly east of the Mississippi River and in the Lake Borgne area. A storm surge of up to $3 \mathrm{~m}$ was estimated south of Lake Pontchartrain and just west of the Mississippi River, with totals decreasing to $\sim 1.5 \mathrm{~m}$ further west near Morgan City (St. Mary Parish). Surge was estimated at over 3 m west of Lake Pontchartrain, decreasing to $0.5-1.5 \mathrm{~m}$ west of Lake Maurepas [24]. The combination of storm surge and strong winds caused the Mississippi River to flow backwards for almost $24 \mathrm{~h}$ [25].

This storm surge and rainfall led to high water levels throughout Southern Louisiana. Many regional rivers, including the Mississippi River, were above flood stage, with water levels threefold to fivefold higher than stages measured before the landfall. Water levels in lakes Maurepas and Pontchartrain similarly increased, with water being pushed out to the west toward LaPlace and surrounding communities from Isaac's counterclockwise winds [24]. Many areas unprotected by the federal levee system were inundated, including the towns LaPlace (St. John the Baptist Parish), Mandeville (St. Tammany Parish), and Slidell (St. Tammany Parish). Sedimentary evidence of Isaac's storm surge inundation in the form of 2-4 cm-thick organic mud and laminated sand deposits was observed in wetlands west of Lake Pontchartrain [26,27].

\section{Materials and Methods}

Accretion data are available from the Coastal Information Management System (CIMS-http://cims.coastal.louisiana.gov) [28], provided by the Louisiana Coastal Protection and Restoration Authority (CPRA). The CIMS is dominated by the voluminous dataset of the Coastal Reference Monitoring System (CRMS), a network of 390 wetland sites across coastal Louisiana established in 2003 as a result of the collaboration between the CPRA and the United States Geological Survey (USGS), with the overarching goal of determining wetland conditions and the effectiveness of restoration projects [29] (Figure 2). At each CRMS study site, a host of data was collected or measured according to standard methodologies and at specific time intervals, including geological (i.e., bulk density, \% organic, salinity), spatial (i.e., \% water surface, \% land cover), hydrological (i.e., salinity, temperature), and vegetation (i.e., classification, dominant taxa) data [30]. Site monitoring and data collection is constant, with the CIMS providing new data available for download every week.

A complete and consistent methodology was designed for vertical accretion station establishment, monitoring, and measurements [30]. The monitoring and measurements were administered by numerous organizations and agencies, including the Coastal Protection and Restoration Authority, Coastal Estuary Services LLC, Louisiana Department of Natural Resources, United States Geological Survey, and National Wetlands Research Center. To determine accretion, a series of $50 \times 50 \mathrm{~cm}$ plots were created adjacent to constructed boardwalks in areas designated as data collection stations, located proximate to their corresponding CRMS site. A marker horizon consisting of white feldspar clay was deposited throughout the plot on the day of station establishment. This feldspar marker was deposited in groups of stations approximately every two years. Potential pitfalls of the feldspar technique to measure vertical accretion include its susceptibility to erosion or degradation and its limitation to only relatively short-term measurements (i.e., months to years). On the other hand, this methodology is cost effective and can be easily replicated throughout the numerous stations located statewide. It can also offer easy-to-interpret, high-resolution measurements covering brief time intervals. Care was administered to avoid sampling for accretion at floating marsh sites [30]. A cryogenic coring method was used to collect the wetland sediment sample on the day of station sampling [31]. The cores were visually divided into four equal sections, and accretion above the marker horizon (in millimeters) was measured from each section by means of calipers. Data collection stations were generally sampled twice per year for two years, and then sampled once every 1.5 years thereafter. Stations were eventually abandoned if accretion could not be determined (e.g., feldspar layer badly damaged or missing) [30]. For the present analysis, we downloaded the accretion data from the CIMS website and input into our own GIS. The following fields were included for each accretion record: Station ID, Group, Sample Date, Sample Time, Establishment Date, Establishment Time, Core X:Y (coordinate grid within a $50 \times 50 \mathrm{~cm}$ plot), Core Conditions, Personnel, and Notes. As of October 2015, the CIMS contained over 
29,000 accretion records from thousands of data collection stations, spread across 390 CRMS wetland sites covering the entire coastal zone of Louisiana since 1996 (Figure 2). Additionally included in this analysis were accretion rates from project data collection stations available in the CIMS (Bayou Dupont, Marsh Island) but not belonging to the CRMS.

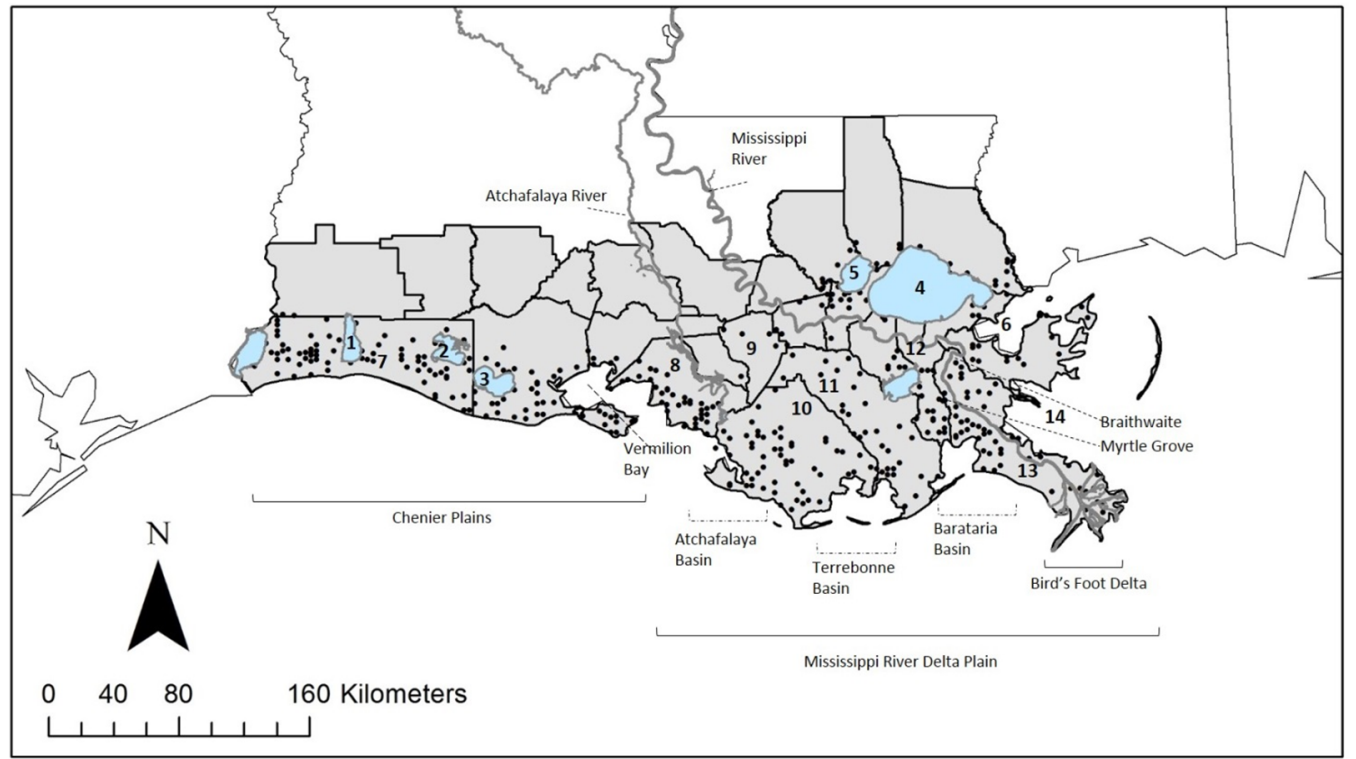

Figure 2. Locations (black dots) of all 390 CRMS sites are presented. Our study area covers 24 parishes throughout Southern Louisiana. Relevant geographical features and political landmarks mentioned in the text are labeled. 1-Calcasieu Lake; 2-Grand Lake; 3-White Lake; 4-Lake Pontchartrain; 5-Lake Maurepas; 6-Lake Borgne; 7-Cameron Parish; 8-St. Mary Parish; 9-Assumption Parish; 10-Terrebonne Parish; 11-Lafourche Parish; 12-Jefferson Parish; 13-Plaquemines Parish; 14-Breton Sound.

We created new columns to this dataset to facilitate comparisons between sites and areas during the same time period, along with different time periods. Accretion measurements for each core (up to four measurements, if applicable) were averaged to create a single measurement, converted to centimeters. The number of days between station establishment (feldspar deposition) and sampling (core collection) was determined and converted to decimal years. Accretion measurements were divided by the decimal year to extrapolate a rate $(\mathrm{cm} /$ year) for each data collection station. All station rates belonging to the same CRMS site were averaged, and the mean value assigned to the particular CRMS site. For the few projects and data collection stations not belonging to the CRMS, a similar methodology was used, and a central point (site) was assigned to adjacent stations by the authors.

Accretion rates were sorted into three different time periods with reference to the landfall of Hurricane Isaac (Figure 3). One period contains accretion rates from sites containing stations with an establishment date before Isaac's landfall (on 28 August 2012), and a sample date after landfall to capture the hurricane's deposit (if any) (Table 1). To capture a sufficient number of data points while focusing squarely on Isaac's sedimentary input, a maximum interval of $\sim 7$ months (213 days) was chosen between the establishment date (ranging from 13 February 2012 to 5 June 2012) and sample date (3 September 2012 to 14 November 2012). While defining shorter time periods (maximum time interval of 4-6 months) would be most ideal to determine hurricane impacts while limiting seasonal impacts on accretion, these efforts provided unsatisfactory results as the spatial coverage became reduced. In total, 535 accretion records from 188 CRMS sites were obtained from data collection stations during this time period. A total of 302 records covering 100 sites (including 2 non-CRMS sites) do not contain accretion measurements during this period due to a missing feldspar layer. 
Temporal Distribution of Data Collection Station Establishment and Sampling

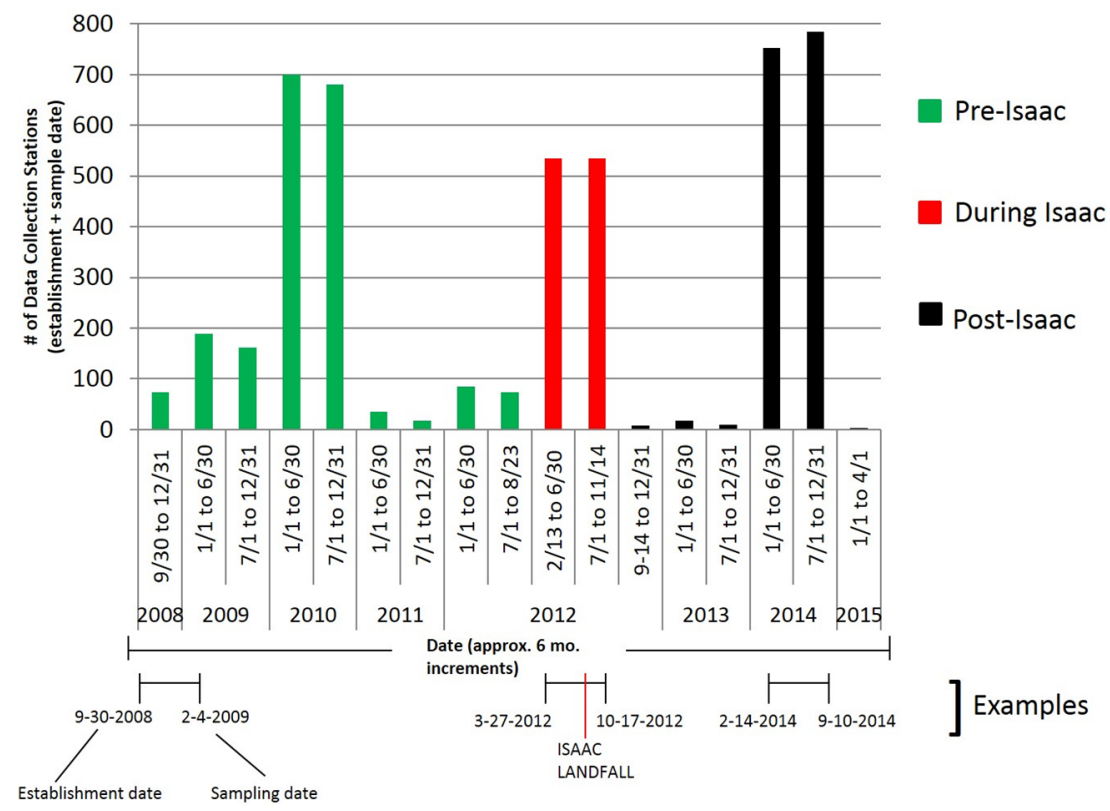

Figure 3. Temporal distribution of data collection stations analyzed in this study. Bars indicate number of accretion records (data collection stations) per time period with an establishment and/or sampling date. Results are color-coded by time period. At the bottom is an example of three sampling intervals with hypothetical establishment and sampling dates, each representing the pre-, during, or post-Isaac period.

Table 1. Collection station information showing dates of station establishment and sampling, along with duration of sampling period.

\begin{tabular}{cccc}
\hline \multicolumn{4}{c}{ Station Establishment and Sampling Data } \\
\hline Category & Pre Isaac & During Isaac & Post Isaac \\
\hline \# of Accretion Records (Data Collection Stations) & 1007 & 535 & 802 \\
Earliest Station Establishment & $9 / 30 / 2008$ & $2 / 13 / 2012$ & $9 / 14 / 2012$ \\
Latest Station Establishment & $4 / 18 / 2012$ & $6 / 5 / 2012$ & $9 / 16 / 2014$ \\
Earliest Sampling Date & $2 / 3 / 2009$ & $9 / 3 / 2012$ & $3 / 19 / 2013$ \\
Latest Sampling Date & $8 / 23 / 2012$ & $11 / 14 / 2012$ & $4 / 1 / 2015$ \\
Longest Sampling Period (Days) & 213 & 213 & 212 \\
Shortest Sampling Period (Days) & 64 & 141 & 62 \\
Average Sampling Period (Days) & 175 & 193 & 175 \\
\hline
\end{tabular}

Two baseline periods were used to compare with the Isaac period (Figure 3, Table 1). One period spanned the time before Hurricane Isaac and after Hurricane Gustav (1 September 2008), the previous landfalling hurricane in coastal Louisiana, so that it represented a time without any hurricane-induced sedimentation in the state's wetlands. This period contains 1007 accretion rates from 272 sites (including 3 non-CRMS sites). An additional 495 records from 163 sites (including 2 non-CRMS sites) lack an accretion measurement due to a missing feldspar layer. Establishment dates ranged from 30 September 2008 to 18 April 2012, and sample dates began on 3 February 2009 and extended to 23 August 2012. Another baseline period was created to determine accretion rates after Isaac. There were 802 accretion records in this subset from 278 sites (including 5 non-CRMS sites). A total of 336 records covering 112 sites (including 4 non-CRMS sites) do not contain an accretion rate due to a missing feldspar layer. The establishment dates ranged from 14 September 2012 to 16 September 2014, and the sample dates from 19 March 2013 to 1 April 2015. Similar to the period defined before Isaac, this post-Isaac period did not contain any impacts from landfalling hurricanes. Notably, out of the 390 total CRMS sites, 132 
contain an accretion measurement for each of all three time periods (pre-, during, and post-) that would permit direct comparison of accretion rate changes within the same site (referred to as 'common sites').

We applied the Inverse Distance Weighting (IDW) method, which is one of the most frequently used interpolation techniques in GIScience [32], to map the spatial pattern of accretion rates for each time period. This technique is a deterministic interpolation method based on Tobler's First Law of Geography [33]. IDW can effectively smooth the local variation and uncover the general trend of the spatial distribution of the dataset. Additionally, the result from IDW is easier to interpret at the data exploration stage when there is no established assumption about the distance or directional bias in the dataset. In future research, the spatial pattern of the dataset will be further evaluated and the sensitivity of the results to different interpolation techniques will be systematically compared. An unknown data value $(\hat{y}) S_{0}$ from location $S_{0}$ is determined by:

$$
(\hat{y}) S_{0}=\sum_{i=1}^{n} \lambda_{i} y\left(S_{i}\right)
$$

where $y=$ observed values, $S_{i}=$ sampled locations, and $\lambda_{i}=$ weights, defined as:

$$
\lambda_{i}=d_{0 i}^{-\alpha} / \sum_{i}^{n} d_{0 i}^{-\alpha}
$$

where:

$$
\sum_{i}^{n} \lambda_{i}=1
$$

The parameter $\alpha$ controls the distance decay effect from the estimated point to the sample point. In this study, $\alpha$ is set to the default value of 2 . The attribute value of every unknown point is estimated from the 50 nearest neighborhood points. ArcGIS 10.2 was used for interpolation and data display.

\section{Results}

During the pre-Isaac period, the average accretion rate at the sites was $2.89 \mathrm{~cm} /$ year, with a range of 0 to $35.08 \mathrm{~cm} /$ year (Table 2). The maximum accretion rate, derived at the Bird's Foot Delta from one site with two accretion records established on 5 October 2011 and sampled on 27 March 2012, is likely an anomaly due to bioturbation, which was noted during core collection based on the existence of animal tracks in the vicinity. Site accretion rates were generally low throughout the study area, especially in the Chenier Plains where rates ranged from 0 to $9.43 \mathrm{~cm} /$ year (Figure 4A). The Atchafalaya Basin and Mississippi River Delta similarly contained low accretion rates, but anomalously high accretion rates occurred at a few sites near the Atchafalaya River $(18.72 \mathrm{~cm} /$ year $)$, the southern edge of the Bird's Foot Delta (35.08 cm/year), the western edge of Plaquemines Parish $(11.39 \mathrm{~cm} /$ year), and north of Lake Maurepas (12.63 cm/year). Adjacent to the Mississippi River in Plaquemines Parish, site rates were as low as $0.36 \mathrm{~cm} /$ year and spiked up to $35.08 \mathrm{~cm} /$ year, despite site rates of generally less than $6 \mathrm{~cm}$ /year in this area. The interpolated map (Figure 5A) indicates that the area west of Calcasieu Lake contained the lowest accretion rates (0-1.61 cm/year). Accretion increased $(1.61-3.21 \mathrm{~cm} /$ year) in the vicinity of and east of Calcasieu Lake, with small patches of higher accretion rates adjacent to Grand Lake and White Lake. Moderate accretion rates $(3.21-8.39 \mathrm{~cm} /$ year) covered most of the Atchafalaya Basin, with accretion generally decreasing (0-3.21 cm/year) to the east except in the Bird's Foot Delta, north of Lake Maurepas, and south of Lake Borgne. 
Table 2. Accretion statistics showing the \# of sites and descriptive statistics regarding accretion rates for all three time periods analyzed in this study.

\begin{tabular}{cccc}
\hline \multicolumn{4}{c}{ ACCRETION STATISTICS } \\
\hline Category & Pre Isaac & During Isaac & Post Isaac \\
\hline \# of Sites & 272 & 188 & 278 \\
Mean (cm/year) & 2.89 & 4.04 & 2.38 \\
Standard Error & 0.18 & 0.33 & 0.21 \\
Mean, common sites (cm/year) & 2.85 & 4.39 & 2.13 \\
Median (cm/year) & 2.28 & 2.79 & 1.58 \\
Range (cm/year) & 0 to 35.08 & 0 to 28.84 & 0 to 46.58 \\
Standard Deviation & 2.98 & 4.48 & 3.49 \\
\hline
\end{tabular}

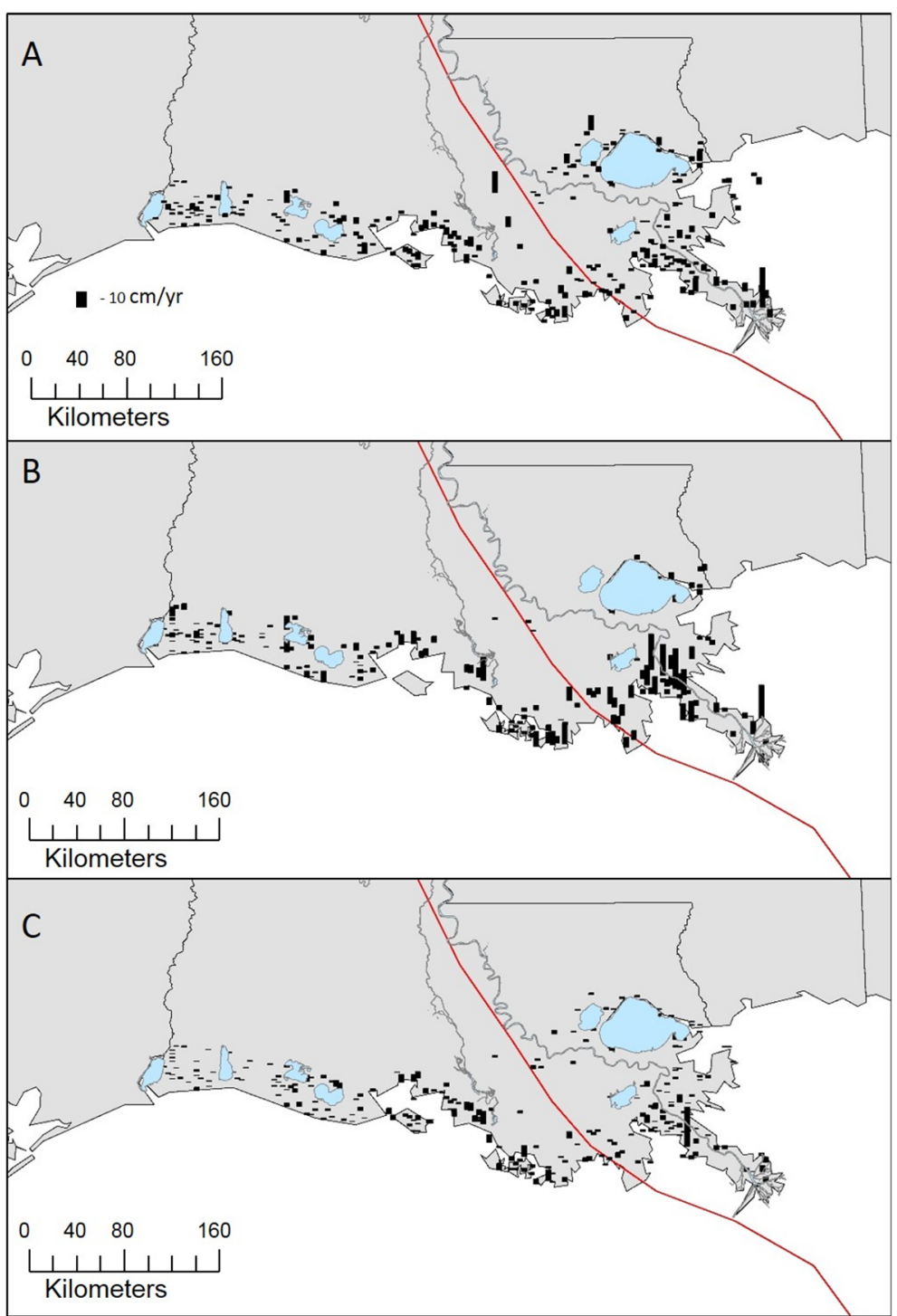

Figure 4. Accretion rates (cm/year) at all sites (vertical bars) measured during three time periods. (A) before Isaac; (B) encompassing Isaac; (C) after Isaac. Red line shows storm track of Hurricane Isaac.

During the period encompassing Isaac, accretion ranged from 0 to $28.84 \mathrm{~cm} /$ year at the sites, but the average rate reached $4.04 \mathrm{~cm} /$ year, which is $40 \%$ higher than the pre-Isaac period. Sites with low accretion rates dominated the Chenier Plains, with the lowest rates $(0-6.44 \mathrm{~cm} /$ year) from sites nearest the Texas border and surrounding Calcasieu Lake, while moderate rates occurred west of 
Grand Lake (8.9, $11.72 \mathrm{~cm} /$ year) (Figure 4B). Site accretion increased throughout the central and eastern parts of our study region, with moderate accretion rates located in the Atchafalaya Basin (1.47-17.35 cm/year), Barataria Basin (0.44-14.81 cm/year), and adjacent to lakes Pontchartrain and Maurepas (0.82-8.72 cm/year). Anomalously high rates (ranging from 23.77-28.84 cm/year) are located east of the Isaac track, particularly adjacent to the Mississippi River and throughout the Bird's Foot Delta. Notably, accretion rates were highest in the vicinity of the Isaac track, with an average site accretion of $6.10 \mathrm{~cm} /$ year within $70 \mathrm{~km}$ of the track, compared to only $2.34 \mathrm{~cm} /$ year for the remaining sites lying outside of this area (Figure 6). Interpolated regions with mostly low accretion rates $(0-3.21 \mathrm{~cm} /$ year) dominated the entire Chenier Plains, while only small, isolated areas existed east of the Atchafalaya River. The Mississippi River Delta generally experienced at least moderate accretion (over $3.21 \mathrm{~cm} /$ year), while small areas underwent high accretion $(>8.39 \mathrm{~cm} /$ year) in the Barataria Basin and Bird's Foot Delta, along with a larger area adjacent to the Mississippi River in Plaquemines and Jefferson Parishes (Figure 5B).

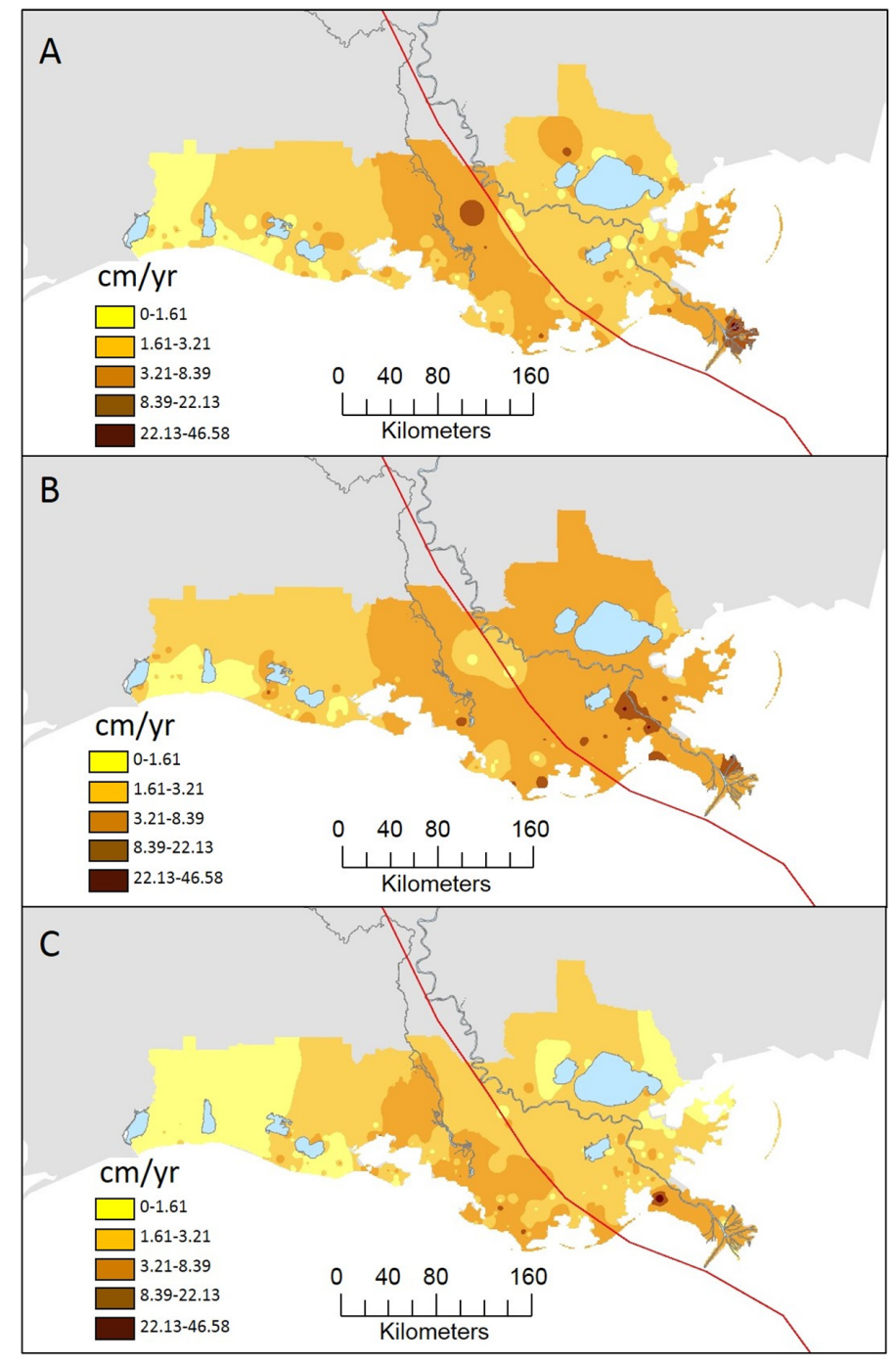

Figure 5. Interpolated accretion rates (cm/year) for three time periods. (A) before Isaac; (B) encompassing Isaac; (C) after Isaac.

During the period after Isaac, accretion at the sites ranged from 0 to $46.58 \mathrm{~cm} /$ year at the sites, with an average rate of $2.38 \mathrm{~cm} /$ year Sites in the Chenier Plains contained mostly low accretion rates $(0-7.54 \mathrm{~cm} /$ year), with most sites under $3 \mathrm{~cm} /$ year (Figure $4 \mathrm{C}$ ). Site accretion increased to the east, but mostly in locations nearest the coast, with anomalously high rates along the southern 
edge of the Atchafalaya Basin (9.01, $9.19 \mathrm{~cm} /$ year), southern Terrebonne Parish (12.64 cm/year), and Plaquemines Parish (46.58 cm/year). This anomalously high maximum rate for Plaquemines Parish comes from a site bordering vast open water areas, protected from the Gulf of Mexico only by intermittent barrier islands. The tremendous sediment and wrack deposition documented for this site during this time period suggests a high degree of localized flooding, likely storm-driven. Site accretion was generally low $(0-5.05 \mathrm{~cm} /$ year $)$ in the Lake Pontchartrain and Maurepas areas. With the exception of large swaths of areas in the Atchafalaya Basin, Terrebonne Basin, and Bird's Foot Delta with at least moderate accretion totals $(>3.21 \mathrm{~cm} /$ year), Southern Louisiana generally experienced low accretion $(0-1.61 \mathrm{~cm} /$ year) during this period, especially the Chenier Plains and Lake Pontchartrain/Maurepas area (Figure 5C).

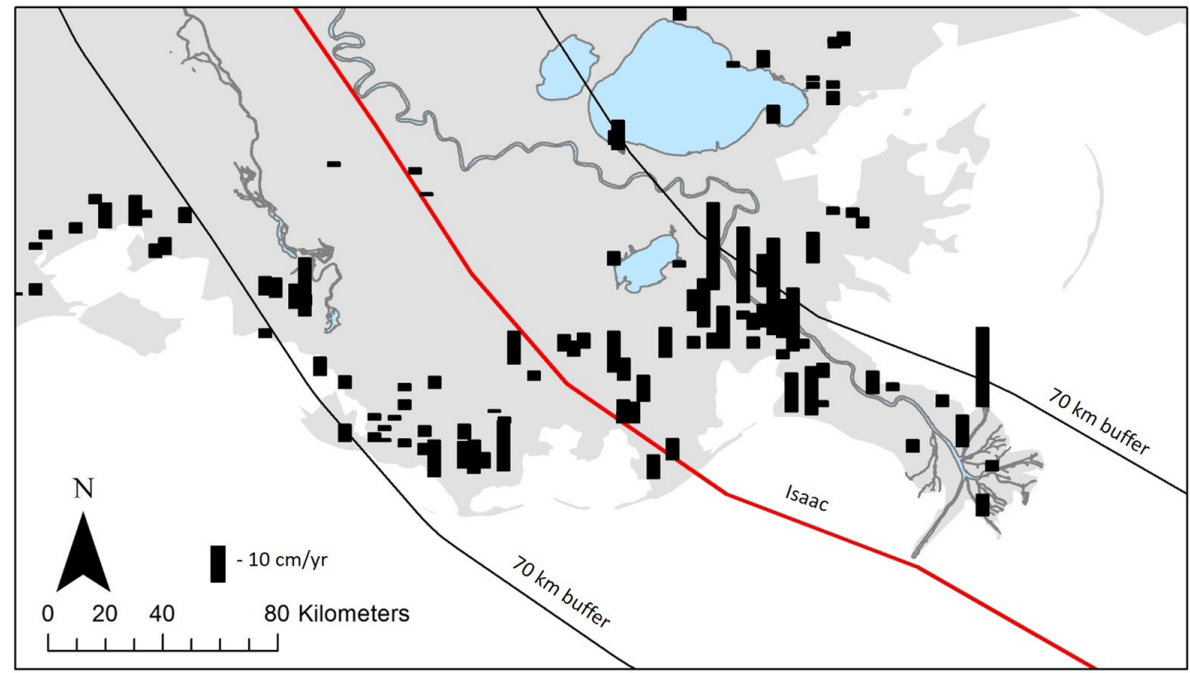

Figure 6. Accretion rates at sites in Southeastern Louisiana within and outside of a $70 \mathrm{~km}$ buffer (black lines) from Isaac's track (red line). Sites located within this buffer contained an average accretion rate of $6.10 \mathrm{~cm}$ /year, compared to only $2.34 \mathrm{~cm}$ /year for all sites in the state outside of this area.

\section{Discussion}

Rates from our pre- and post-Isaac datasets are consistent with published rates that use a similar feldspar technique, which further supports the accuracy and validity of the CRMS dataset. In the Chenier Plains, the typical, non-storm accretion rates varied from $0.61 \mathrm{~cm} /$ year at Rockefeller State Park [34] to 0.35-1.13 cm/year in Cameron Parish [35]. Rates from Lake Pontchartrain's north shore were similar, ranging from 0.21 to $1.18 \mathrm{~cm}$ /year [14]. Accretion on the Deltaic Plain was slightly higher, ranging from $0.3-1.84 \mathrm{~cm} /$ year $[6,34,35]$ with the highest rates occurring near river diversions [6].

\subsection{Spatial Variability in Accretion during Isaac Period}

The landfall of Hurricane Isaac played a critical role in increasing vertical accretion in the wetlands of southern Louisiana. The highest accretion rates occurred along the eastern side of the Isaac track, specifically the Bird's Foot Delta and adjacent to the Mississippi River in Plaquemines Parish, which includes the "Eastbank" and "Westbank" areas. Storm surge entered the Eastbank from the Breton Sound area, overtopping a non-federal back levee and trapping water between it and the Mississippi River levee, devastating the town of Braithwaite with 13 foot $(3.96 \mathrm{~m})$ storm surge while flooding an 18-mile stretch of the Eastbank [23,24,36], likely the main cause for remarkable accretion rates ( $>8.39 \mathrm{~cm}$ /year). A larger area of high accretion rates over $8.39 \mathrm{~cm} /$ year covers the Westbank, which includes small areas over $22.13 \mathrm{~cm}$ /year (Figure 5B). These areas provide evidence of mass sediment deposition due to riverine flooding, caused by a combination of storm surge entering the Mississippi River through its southernmost tributaries, and heavy rainfall totals due to Isaac's slow-moving 
track. Mississippi River levees were overtopped south of Braithwaite, probably at the low elevation, non-federal levee near Myrtle Grove [24].

A notable area of minimal accretion $(0.78-1.84 \mathrm{~cm} /$ year) was located in northern Assumption Parish directly on Isaac's track but between the Mississippi River and the Atchafalaya River (Figures $4 \mathrm{~B}$ and $5 \mathrm{~B})$. This site had a very high accretion rate $(18.72 \mathrm{~cm} /$ year) during the period before Isaac but a relatively low rate $(1.11 \mathrm{~cm} /$ year $)$ attributable to the storm. The anomalously high accretion at this site in the pre-Isaac period was due to freshwater flooding in the Atchafalaya drainage basin during the exceptionally high water event of May 2011, when excessive discharge from the Old River Control Structure prompted the opening of the Morganza Spillway to release the pressure of overbank flooding on the levee system [37]. The relatively low accretion during the period encompassing Isaac can be explained by the lack of freshwater flooding at this site between the two heavily-leveed rivers during the Isaac event. At least moderate rates of accretion $(>3.21 \mathrm{~cm} /$ year $)$ occurred throughout much of the remainder of the state east of the $70-\mathrm{km}$ buffer, along with an area stretching to the north shore of Vermilion Bay, approximately $100 \mathrm{~km}$ west of the track (Figure 5B). Since storm surge was minimal and offshore winds were dominant west of the track, the increase in accretion rates west of Isaac's track occurred from the rainfall-induced flooding of coastal and inland lakes, bays, rivers, and tributaries, leading to inorganic sediment deposition throughout the wetlands. Further west in the Chenier Plains, low to moderate accretion rates suggests that Isaac-induced flooding was either non-existent, or occurred solely in small, select areas near lake basins.

\subsection{Temporal Variability in Accretion}

For the storm period, the average of site accretion rates was $40 \%$ and $70 \%$ greater than the periods before and after the event, respectively. A comparison of interpolated accretion rates during the Isaac period to pre- and post-Isaac periods (Figure 7A,B) indicates that the largest differences occurred in the areas east of the storm track, especially along the Mississippi River south of Lake Pontchartrain. Despite small areas in the Bird's Foot Delta and north of lakes Pontchartrain and Maurepas that did not experience increased accretion, the areas east of the storm track generally received at least $1 \mathrm{~cm} /$ year more accretion than before or after the event. A sizeable positive anomaly in accretion (4-6 cm/year) occurred in a large and irregularly-shaped swath bordering the Mississippi River, stretching from central Plaquemines Parish to Lake Pontchartrain. Inside this area lies a smaller section that experienced an accretion spike of 6-28 cm/year (Figure 7A,B) due to its proximity to the Mississippi River, which overflowed its leveed banks and flooded the surrounding floodplains and bottomlands. A comparison of the Isaac period to the post-storm period shows the same area of significant storm-induced accretion along the Mississippi River. The comparison of the Isaac period to the pre-storm period indicates relatively large changes in accretion throughout the Bird's Foot Delta, which do not occur when analyzing the post-storm image. This suggests that sediment deposition from typical seasonal flooding (i.e., surge from winter storms, stream flooding from intense or prolonged rainfall) is a significant factor controlling accretion for this area.

As expected, areas west of the Isaac storm track experienced insignificant or no increase in accretion from Isaac (Figure 7A,B). A large area of no gain occurred west of the storm track between the Mississippi and Atchafalaya rivers when the Isaac period and pre-Isaac periods are compared (Figure 7A), but this feature disappeared on the map comparing with the post-Isaac period (Figure 7B). Again, this difference can be explained by the high accretion rates caused by the Spring 2011 fluvial flood event in the Atchafalaya basin, whereas no such extreme event occurred in the post-Isaac period. In addition, several areas in the Chenier Plain in Southwestern Louisiana also lack an increase in accretion attributable to Isaac. This is probably due to the significant drop-off in precipitation totals to the west of the storm track, as suggested by precipitation totals of only 0.66 inches $(1.68 \mathrm{~cm})$ and 0.59 inches $(1.50 \mathrm{~cm})$ for Lake Charles and Sulphur, respectively. Moreover, Isaac-induced accretion in coastal marshes in the Chenier Plain was also minimal, as storm surge was no more than 2.2 feet $(0.67 \mathrm{~m})$ in Southwestern Louisiana [23]. 


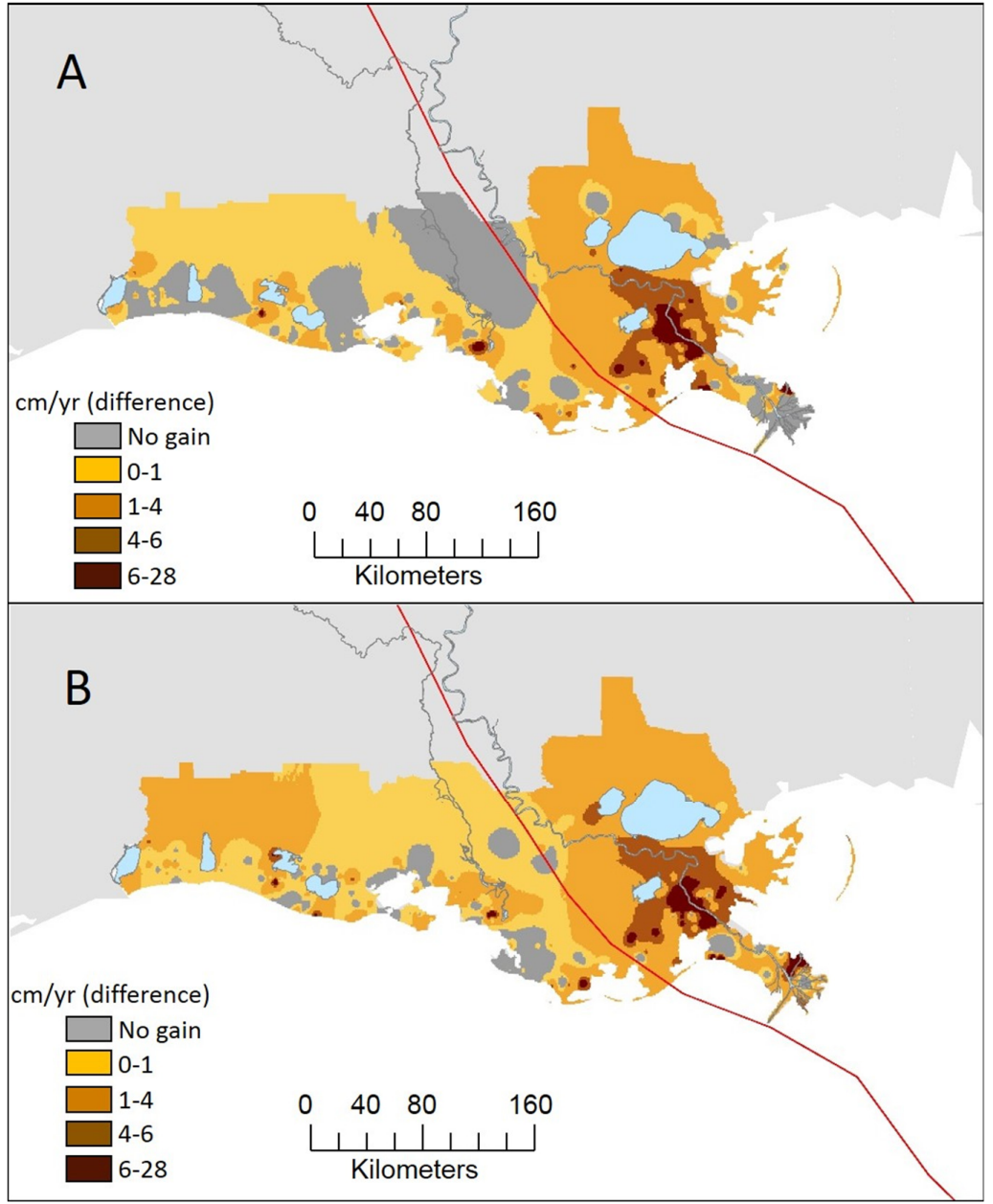

Figure 7. Difference maps showing increases in accretion rates due to Isaac, created by (A) subtracting the pre-Isaac period (Figure 5A) from the Isaac period (Figure 5B); and (B) subtracting the post-Isaac period (Figure 5C) from the Isaac period (Figure 5B).

\subsection{The Role of Hurricanes as "Land-builders" for Coastal Louisiana}

The significance of hurricane-induced sediment deposition in coastal wetlands has recently been emphasized in the literature. Accretion of over $3 \mathrm{~cm}$ was measured throughout the southern Louisiana coast from recent hurricanes Katrina and Rita [38]. Sediment deposition from hurricanes Katrina, Rita, Gustav, and Ike totaled 68, 49, 21, and 33 million metric tons, leading to maximum accretion rates of $21,20,7$, and $17 \mathrm{~g} / \mathrm{cm}^{2}$, respectively [19]. An average yearly total of 5.6 million tons of inorganic sedimentation was determined from tropical cyclones on Louisiana wetlands, deemed an important component in coastal land-building [39]. In addition to the role and contribution of inorganic sediments toward increasing wetland surface elevation and providing stability to marsh substrate, Baustian and Mendelssohn [40] discovered their positive effects on wetland primary production and resilience, partly from the decline in sulfide due to a lessened influence of relative sea level rise. The interaction between inorganic sediment deposition and overall wetland health and stability is complex, however. Tides and heavy precipitation can remove recently deposited loose and unconsolidated material [18], while sediments can weigh on wetland surfaces, causing a decrease in elevation to pre-input levels in as little as 2.5 years [41]. Meanwhile, elevated accretion rates from marsh flooding could be from accumulated organic matter from root growth, instead of mineral accumulation via deposition [42]. Large-scale assessments of hurricane-induced sediment deposition and its subsequent long-term effects on wetland elevation, while incorporating impacts of subsidence, sediment compaction, and 
other environmental factors (salinity, hydrology) affecting wetland vertical accretion, are therefore requisite for coastal protection and restoration planning for Louisiana.

While this work focuses on wetland accretion and depositional processes, it is imperative to also consider a hurricane's propensity to cause land loss along coastal Louisiana. Despite their role in sediment deposition and accretion, recent events including Ike, Gustav, Katrina, and Rita were responsible for significant levels of ecological disturbance, marsh flooding, and denudation throughout Louisiana. This includes, but is not limited to, increasing the size of open water bodies [43], marsh erosion [44], increasing wetland salinity, landscape change from wetland to mudflat, removal of floating marsh, and creation of small ponds [45]. Balancing the results from this study with a similar large-scale assessment of wetland erosion and loss due to recent hurricanes would be an ideal "two-prong" approach to understanding regional coastal dynamics.

\section{Conclusions}

This study analyzes the spatial and temporal variability in wetland accretion rates in the light of the impact of Hurricane Isaac, a category 1 storm, making landfall in late August, 2012 at the Louisiana coast. This analysis was based on the voluminous Coastal Reference Monitoring System dataset, which contains thousands of accretion rates measured from hundreds of sites located throughout Southern Louisiana. More important, the CRMS dataset has a high fidelity and reliability, as it was collected with a standardized methodology, thus allowing for spatial and temporal smoothing and comparison. We compiled the accretion rates within time periods of no longer than seven months encompassing the Isaac event measured for 188 sites across coastal Louisiana, and compared that with accretion rates measured within time periods of comparable lengths at 272 and 278 sites before and after the Isaac event, respectively.

The results from this study shed light on our research questions. First, the landfall of Hurricane Isaac made a significant impact on accretion rates throughout Southern Louisiana. Isaac's slow-moving track led to high rainfall totals and storm surge inundation, both responsible for flooding Southern Louisiana and causing massive sediment deposition along the low-lying Mississippi River Delta. The data suggest that during the period encompassing Isaac's landfall, average accretion rate from all sites was $4.04 \mathrm{~cm} /$ year, compared to $2.89 \mathrm{~cm}$ /year before Isaac and $2.38 \mathrm{~cm} /$ year after, representing an increase of $40 \%$ and $70 \%$, respectively. Secondly, accretion rates during the Isaac period were highest nearest the coast and within $70 \mathrm{~km}$ of Isaac's track, with an average rate of $6.10 \mathrm{~cm} /$ year, compared to only $2.34 \mathrm{~cm} /$ year outside of the buffer. Finally, and most remarkably, the highest accretion rates occurred in areas adjacent to the Mississippi River, about 50-70 km away to the east of the storm track. The alluvial wetlands and floodplain sites in this area, specifically the Eastbank and Westbank areas of Jefferson Parish and northern Plaquemines Parish, generally contained $>6 \mathrm{~cm} /$ year higher accretion rates during the Isaac period than before and after the event. While storm surge flooding east of the track likely played a role toward increased accretion, this spatial pattern strongly suggests that the higher accretion rates attributed to Isaac were caused largely by overbank flooding from the Mississippi River and its distributaries during and immediately after the event. This provides further evidence of the importance of riverine flooding to land building throughout Southern Louisiana [46].

This study demonstrates the role of hurricanes in land-building in the wetlands of coastal Louisiana by using Hurricane Isaac as an example. Our ongoing efforts include extending this analysis from Isaac to other recent hurricane events (Katrina, Rita, Gustav, Ike, Cindy) to understand their respective roles contributing to the spatial and temporal variability of accretion rates in Louisiana's coastal wetlands.

Acknowledgments: This work is supported by a grant from the Coupled Natural-Human Dynamics Program of the National Science Foundation (CNH-1212112). We thank Sarai Piazza from the United States Geological Survey for assistance in understanding the details and methodologies used to determine vertical accretion rates for the CRMS dataset. We also thank Torbjörn Törnqvist and two anonymous reviewers for their comments and suggestions to improve this manuscript. Any findings, opinions, or conclusions presented in this work are those of the authors and do not necessarily reflect the views of the National Science Foundation.

Author Contributions: Thomas Bianchette and Kam-biu Liu developed the conceptual framework for this manuscript. Thomas Bianchette retrieved the data from the Coastal Information Management System, performed 
the data analysis, produced the figures, and wrote the paper. Yi Qiang helped with the GIS analysis, which includes choosing a proper interpolation method for data display and producing the final figures. Nina Lam aided in the GIS analysis and interpretation for this manuscript. Kam-biu Liu, Yi Qiang, and Nina Lam all read and made improvements to the manuscript.

Conflicts of Interest: The authors declare no conflicts of interest.

\section{References}

1. Couvillion, B.R.; Barras, J.A.; Steyer, G.D.; Sleavin, W.; Fischer, M.; Beck, H.; Trahan, N.; Griffin, B.; Heckman, D. Land area change in coastal Louisiana from 1932 to 2010. U.S. Geological Survey Scientific Investigations Map 3164, Scale 1:265,000; United States Geological Survey: Reston, VA, USA, 2011; p. 12.

2. Church, J.A.; Clark, P.U.; Cazenave, A.; Gregory, J.M.; Jevrejeva, S.; Levermann, A.; Merrifield, M.A.; Milne, G.A.; Nerem, R.S.; Nunn, P.D.; et al. Sea level change. In Climate Change 2013: The Physical Science Basis. Contribution of Working Group 1 to the Fifth Assessment Report of the Intergovernmental Panel on Climate Change; Stocker, T.F., Qin, D., Plattner, G.-K., Tignor, M., Allen, S.K., Boschung, J., Nauels, A., Xia, Y., Bex, V., Midgley, P.M., Eds.; Cambridge University Press: Cambridge, UK, 2013; pp. 1137-1216.

3. Barras, J.A.; Beville, S.; Britsch, D.; Hartley, S.; Hawes, S.; Johnston, J.; Kemp, P.; Kinler, Q.; Martucci, A.; Porthouse, J.; et al. Historical and Projected Coastal Louisiana Land Changes: 1978-2050; USGS Open File Report 03-334; U.S. Geoogca Survey: Lafayette, LA, USA, 2003; p. 39.

4. Lam, N.S.N.; Arenas, H.; Li, Z.; Liu, K.B. An estimate of population impacted by climate change along the U.S. Coast. J. Coastal Res. 2009, SI 56, 1522-1526.

5. Qiang, Y.; Lam, N.S.N. Modeling land use and land cover changes in a vulnerable coastal region using artificial neural networks and cellular automata. Environ. Monit. Assess. 2015, 187, 1-16. [CrossRef] [PubMed]

6. Lane, R.R.; Day, J.W., Jr.; Day, J.N. Wetland surface elevation, vertical accretion, and subsidence at three Louisiana estuaries receiving diverted Mississippi River water. Wetlands 2006, 26, 1130-1142. [CrossRef]

7. Cahoon, D.R.; Reed, D.J.; Day, J.W., Jr. Estimating shallow subsidence in microtidal salt marshes of the southeastern United States: Kaye and Barghoorn revisited. Mar. Geol. 1995, 128, 1-9. [CrossRef]

8. Penland, S.; Ramsey, K.E. Relative sea-level rise in Louisiana and the Gulf of Mexico: 1908-1988. J. Coastal Res. 1990, 6, 323-342.

9. Kolker, A.S.; Allison, M.A.; Hameed, S. An evaluation of subsidence rates and sea-level variability in the northern Gulf of Mexico. Geophys. Res. Lett. 2011, 38, L21404. [CrossRef]

10. Delaune, R.D.; Patrick, W.H.; Buresh, R.J. Sedimentation-rates determined by ${ }^{137}$ Cs dating in a rapidly accreting salt-marsh. Nature 1978, 275, 532-533. [CrossRef]

11. Delaune, R.D.; Baumann, R.H.; Gosselink, J.G. Relationships among vertical accretion, coastal submergence, and erosion in a Louisiana Gulf-Coast marsh. J. Sediment Petrol. 1983, 53, 147-157.

12. Delaune, R.D.; Whitcomb, J.H.; Patrick, W.H.; Pardue, J.H.; Pezeshki, S.R. Accretion and canal impacts in a rapidly subsiding wetland. $1 .{ }^{137} \mathrm{Cs}$ and ${ }^{210} \mathrm{~Pb}$ techniques. Estuaries 1989, 12, 247-259. [CrossRef]

13. Baumann, R.H.; Day, J.W.; Miller, C.A. Mississippi deltaic wetland survival—Sedimentation versus coastal submergence. Science 1984, 224, 1093-1095. [CrossRef] [PubMed]

14. Brantley, C.G.; Day, J.W., Jr.; Lane, R.R.; Hyfield, E.; Day, J.N.; Ko, J.-Y. Primary production, nutrient dynamics, and accretion of a coastal freshwater forested wetland assimilation system in Louisiana. Ecol. Eng. 2008, 34, 7-22. [CrossRef]

15. Wilson, C.A.; Allison, M.A. An equilibrium profile model for retreating marsh shorelines in southeast Louisiana. Estuar. Coast. Shelf Sci. 2008, 80, 483-494. [CrossRef]

16. Jarvis, J.C. Vertical Accretion Rates in Coastal Louisiana: A Review of the Scientific Literature; United States Army Engineer Research and Development Center: Vicksburg, MS, USA, 2010; p. 14.

17. Nyman, J.A.; Crozier, C.R.; Delaune, R.D. Roles and patterns of hurricane sedimentation in an estuarine marsh landscape. Estuar Coast Shelf Sci. 1995, 40, 665-679. [CrossRef]

18. Cahoon, D.R.; Reed, D.J.; Day, J.W.; Steyer, G.D.; Boumans, R.M.; Lynch, J.C.; McNally, D.; Latif, N. The influence of Hurricane Andrew on sediment distribution in Louisiana coastal marshes. J. Coastal Res. 1995, SI 21, 280-294.

19. Tweel, A.W.; Turner, R.E. Landscape-scale analysis of wetland sediment deposition from four tropical cyclone events. PLoS ONE 2012, 7, e50528. [CrossRef] [PubMed] 
20. Roberts, H.H. Dynamic changes of the Holocene Mississippi River Delta Plain: The delta cycle. J. Coastal Res. 1997, 13, 605-627.

21. McBride, R.A.; Taylor, M.J.; Byrnes, M.R. Coastal morphodynamics and Chenier-Plain evolution in southwestern LA, USA: A geomorphic model. Geomorphology 2007, 88, 367-422. [CrossRef]

22. Sasser, C.E.; Visser, J.M.; Mouton, E.; Linscombe, J.; Hartley, S.B. Vegetation Types in Coastal Louisiana in 2013. U.S. Geological Survey Scientific Investigations Map 3290, 1 Sheet, Scale 1:550,000; United States Geological Survey: Lafayette, LA, USA, 2014.

23. Berg, R. Hurricane Isaac (al092012) 21 August-1 September 2012; Technical report for National Oceanic and Atmospheric Administration/National Weather Service: Miami, FL, USA, 2013.

24. Hurricane Isaac with and without 2012 100-Year HSDRRS Evaluation; Technical report for United States Army Corps of Engineers: Washington, DC, USA, 2013; p. 230.

25. Demas, A. Mississippi River Flows Backwards Due to Isaac; United States Geological Survey Newsroom: Reston, VA, USA, 2012.

26. Liu, K.B.; McCloskey, T.A.; Ortego, S.; Maiti, K. Sedimentary signature of Hurricane Isaac in a Taxodium swamp on the western margin of Lake Pontchartrain, Louisiana, USA. In Sediment Dynamics from the Summit to the Sea; Xu, Y.J., Allison, M.A., Bentley, S.J., Collins, A.L., Erskine, W.D., Golosov, V., Horowitz, A.J., Stone, M., Eds.; International Association of Hydrological Sciences: Wallingford, UK, 2014a; pp. 421-428.

27. Liu, K.B.; McCloskey, T.A.; Bianchette, T.A.; Keller, G.; Lam, N.S.N.; Cable, J.E.; Arriola, J. Hurricane Isaac storm surge deposition in a coastal wetland along Lake Pontchartrain, southern Louisiana. J. Coastal Res. 2014, SI70, 266-271. [CrossRef]

28. Louisiana Coastal Protection and Restoration Authority. Coastal Information Management System. Available online: http:/ / cims.coastal.louisiana.gov/default.aspx (accessed on 11 June 2015).

29. Steyer, G.D. Coastal Reference Monitoring System (CRMS). United States Geological Survey Fact Sheet 2010-3018; United States Geological Survey: Lafayette, LA, USA, 2010; p. 2.

30. Folse, T.M.; Sharp, L.A.; West, J.L.; Hymel, M.K.; Troutman, J.P.; McGinnis, T.E.; Weifenbach, D.; Boshart, W.M.; Rodrigue, L.B.; Richardi, D.C.; Wood, W.B.; Miller, C.M. A Standard Operating Procedures Manual for the Coastwide Reference Monitoring System-Wetlands: Methods for Site Establishment, Data Collection, and Quality Assurance/Quality Control (Revised); Louisiana Coastal Protection and Restoration Authority: Baton Rouge, LA, USA, 2014; p. 228.

31. Cahoon, D.R.; Lynch, J.C.; Knaus, R.M. Improved cryogenic coring device for sampling wetland soils. J. Sediment Res. 1996, 66, 1025-1027. [CrossRef]

32. Longley, P.A.; Goodchild, M.F.; Maguire, D.J.; Rhind, D.W. Geographic Information Systems and Science, 3rd ed.; John Wiley \& Sons: Chichester, UK, 2001; p. 560.

33. Tobler, W.R. Computer movie simulating urban growth in Detroit region. Econ. Geogr. 1970, 46, $234-240$. [CrossRef]

34. Cahoon, D.R. Recent accretion in two managed marsh impoundments in coastal Louisiana. Ecol. Appl. 1994, 4, 166-176. [CrossRef]

35. Cahoon, D.R.; Turner, R.E. Accretion and canal impacts in a rapidly subsiding wetland. 2. Feldspar marker horizon technique. Estuaries 1989, 12, 260-268.

36. Alexander-Bloch, B. Plaquemines after Hurricane Isaac: A Year Later, Residents Redefine What Home Means. Available online: http://www.nola.com/environment/index.ssf/2013/08/plaquemines_after_hurricane_is_3.html (accessed on 6 October 2015).

37. Falcini, F.; Khan, N.S.; Macelloni, L.; Horton, B.P.; Lutken, C.B.; McKee, K.L.; Santoleri, R.; Colella, S.; Li, C.; Volpe, G.; D'Emidio, M.; Salusti, A.; Jerolmack, D.J. Linking the historic 2011 Mississippi River flood to coastal wetland sedimentation. Nat. Geosci. 2012, 5, 803-807. [CrossRef]

38. Turner, R.E.; Baustian, J.J.; Swenson, E.M.; Spicer, J.S. Wetland sedimentation from Hurricanes Katrina and Rita. Science 2006, 314, 449-452. [CrossRef] [PubMed]

39. Tweel, A.W.; Turner, R.E. Contribution of tropical cyclones to the sediment budget for coastal wetlands in Louisiana, USA. Landsc. Ecol. 2014, 29, 1083-1094. [CrossRef]

40. Baustian, J.J.; Mendelssohn, I.A. Hurricane-induced sedimentation improves marsh resilience and vegetation vigor under high rates of relative sea level rise. Wetlands 2015, 35, 795-802. [CrossRef]

41. Graham, S.A.; Mendelssohn, I.A. Functional assessment of differential sediment slurry applications in a deteriorating brackish marsh. Ecol. Eng. 2013, 51, 264-274. [CrossRef] 
42. Nyman, J.A.; Walters, R.J.; Delaune, R.D.; Patrick, W.H., Jr. Marsh vertical accretion via vegetative growth. Estuar. Coast. Shelf Sci. 2006, 69, 370-380. [CrossRef]

43. Palaseanu-Lovejoy, M.; Kranenburg, C.; Barras, J.A.; Brock, J.C. Land loss due to recent hurricanes in coastal Louisiana, USA. J. Coastal Res. 2013, SI 63, 97-109. [CrossRef]

44. Howes, N.C.; Fitzgerald, D.M.; Hughes, Z.J.; Georgiou, I.Y.; Kulp, M.A.; Miner, M.D.; Smith, J.M.; Barras, J.A. Hurricane-induced failure of low salinity wetlands. Proc. Natl. Acad. Sci. USA 2010, 107, 14014-14019. [CrossRef] [PubMed]

45. Morton, R.A.; Barras, J.A. Hurricane impacts on coastal wetlands: A half-century record of storm-generated features from southern Louisiana. J. Coastal Res. 2011, 27, 27-43. [CrossRef]

46. Törnqvist, T.E.; Paola, C.; Parker, G.; Liu, K.B.; Mohrig, D.; Holbrook, J.M.; Twilley, R.R. Comment on Wetland sedimentation from hurricanes Katrina and Rita. Science 2007, 316, 201. [CrossRef] [PubMed] 